\title{
Efek Keadilan Remunerasi, Kompetensi Atasan dan Kohesivitas Kelompok terhadap Withholding Effort
}

\author{
Ida Ayu Kartika Maharani1 ${ }^{*}$, I Gede Riana ${ }^{1}$ I Gede Adnyana Sudibya ${ }^{1}$
}

\begin{abstract}
Withholding effort is a tendency employee to reduce work contribution as the possibility of an individual in giving less than maximum effort on tasks associated with the job. The purpose of this study is to analyze the remuneration fairness influences, supervisor competencies and group cohesiveness on withholding effort. The population in this study was all administrative employees with the status of civil servants and probationary civil servants who were actively working in the Institute Hindu Dharma Negeri Denpasar. The number of respondents were 80 people. The research data was primary data obtained from questionnaires. This study used confirmatory factor analysis and multiple linear regression analysis as analytic technique. The results show that fairness of remuneration has a negative and significant effect on the withholding effort, supervisor competencies has a negative and significant effect on the withholding effort, group cohesiveness has a negative and significant effect on the withholding effort.
\end{abstract}

Keywords: Fairness of remuneration, supervisor competencies, group cohesiveness, withholding effort.

\section{Pendahuluan}

Menahan kontribusi kerja atau yang lebih sering disebut withholding effort adalah sebuah kecenderungan untuk melakukan upaya pengurangan kontribusi kerja sebagai kemungkinan seorang individu dalam memberikan usaha yang kurang maksimal pada tugas yang berhubungan dengan pekerjaan (Kidwell dan Bennett [1], Lin dan Huang [2]). Kemampuan pegawai merupakan komponen penting dalam menghasilkan kinerja yang baik namun motivasi dan kontribusi kerja adalah hal yang tidak kalah penting (Byrne et al. [3], Tracey et al. [4]). Kontribusi kerja memiliki dimensi durasi, intensitas, dan arah (Morris [5]). Withholding effort adalah tidak maksimalnya seorang pegawai membentuk kontribusi kerja dalam indikator durasi, intensitas dan arah (Morris [5]). Dari segi durasi, pegawai mengambil keputusan untuk tidak maksimal dalam memberikan kontribusi kerja selama periode tertentu dan tidak menyelesaikan pekerjaan dalam waktu yang seharusnya. Dalam segi intensitas, pegawai tidak memberikan upaya yang maksimal, bekerja kurang keras, dan memberikan energi yang terbatas dalam penyelesaian tugas. Dalam segi arah, pegawai tidak mengerjakan aktivitas yang ada kaitannya dengan pekerjaan sehingga tidak secara maksimal mendorong tercapainya tujuan organisasi. Withholding effort terbagi menjadi empat bentuk yakni job neglect, shirking, free riding dan social loafing (Kidwell dan Martin [6]).

\footnotetext{
${ }^{1}$ Fakultas Ekonomi dan Bisnis, Jurusan Manajemen, Universitas Udayana, Jl. Raya Kampus Universitas Udayana, Jimbaran, Bali 80361, Indonesia. Email: itchyicha@gmail.com.

* Penulis korespondensi
}

Shirking yaitu kecenderungan pegawai saat bekerja sendiri dengan memberikan kontribusi kerja yang kurang maksimal dan tidak mendapatkan konsekuensi apapun. Job neglect yaitu kecenderungan pegawai untuk meninggalkan dan/atau menunda pekerjaan demi preferensi urusan pribadi saat bekerja sendiri. Social loafing yaitu melakukan pekerjaan tidak maksimal pada saat berada dalam kelompok kerja. Free riding yaitu tidak memberikan kontribusi kerja apapun saat bekerja dalam unit kerja karena output yang didapatkan dibagi rata kepada seluruh anggota organisasi.

Organisasi mengalami kerugian akibat pegawai yang menahan kontribusinya (Sagie dan Birati [7]). Withholding effort mempengaruhi efektivitas organisasi tidak hanya secara langsung namun juga secara tidak langsung. Withholding effort oleh pegawai dapat berakibat penghamburan waktu yang dapat dicontoh dan kemudian dilakukan oleh pegawai lain dalam organisasi sehingga menyebabkan beberapa masalah motivasi kerja, selain itu juga berdampak pada komitmen pegawai yang tadinya mampu memenuhi tugas mereka dengan baik menjadi menurun (Kidwell dan Robie [8]).

Instansi pemerintah yang memiliki satuan kerja paling banyak diantara instansi lainnya adalah Kementerian Agama (Kemenag [9]). Hal ini menyebabkan kementerian ini memiliki jumlah pegawai yang sangat banyak mencapai 220.000 orang yang tersebar di seluruh Indonesia. Kepemilikan satuan kerja terbanyak ini tidak serta merta membuat Kementerian Agama memiliki kinerja paling baik diantara instansi pemerintah lainnya. Hal ini terbukti pada tahun 2015 Kementerian Agama masih 
menempati peringkat 56 dari 86 kementerian/ lembaga dengan nilai 62 dalam rapor akuntabilitas instansi pemerintah (Menpan [10]). Hal ini menunjukkan pelaksanaan pertanggungjawaban misi organisasi belum berhasil dengan baik melalui sistem pertanggungjawaban periodik secara maksimal. Institut Hindu Dharma Negeri (IHDN) Denpasar sebagai perguruan tinggi agama di bawah Kementerian Agama memberikan kontribusi pada tingkat akuntabilitas kinerja yang dicapai oleh Kementerian Agama. Capaian serapan anggaran IHDN Denpasar tahun 2014 hanya 70 persen. Hal ini kurang maksimal dan berdampak pada kinerja organisasi, diasumsikan karena adanya permasalahan dalam pengelolaan, pengembangan, pengawasan dan pelayanan teknis yang notabene adalah tugas dari tenaga kependidikan (pegawai).

Permasalahan dalam serapan anggaran yang telah diteliti oleh Herriyanto [11] diakibatkan oleh faktorfaktor antara lain (1) sumber daya manusia pelaksana pengadaan kurang berkompeten, (2) rangkap tugas dalam jabatan panitia pengadaan, (3) ketakutan pejabat atas tuduhan korupsi, (4) keengganan untuk menjadi pejabat pengadaan karena tidak seimbangnya risiko pekerjaan dengan imbalan yang diterima dan, (5) penunjukan panitia pelaksana kegiatan swakelola belum ditetapkan. Salah satu faktor yakni keengganan menjadi pejabat pengadaan karena tidak seimbangnya risiko pekerjaan dengan imbalan yang diterima termasuk kategori shirking.

Teori pertukaran sosial digunakan pada kerangka teori dalam banyak penelitian organisasi yang meneliti interaksi antara pegawai dan organisasi (Cropanzano dan Mitchell [12], van Knippenberg et al. [13]). Teori pertukaran sosial adalah paradigma yang berpengaruh untuk menguji hubungan pertukaran, yang menyatakan bahwa hubungan manusia terbentuk atas analisis biaya dan manfaat subjektif dalam diri. Proposisi yang mendasari adalah kecenderungan seseorang mengulangi tindakan yang dihargai di masa lalu, dan lebih sering berperilaku tertentu yang telah menghasilkan imbalan yang semakin besar sehingga kemungkinan lebih besar untuk melakukannya kembali (Homans [14]). Persepsi pegawai pada pemenuhan kewajiban (misalnya, remunerasi yang adil atas tanggung jawab pekerjaan dan perlakuan yang adil yang diterima) memprediksi rasa kewajiban pegawai terhadap organisasi (Coyle-Shapiro dan Neuman [15]).

Model yang dirancang oleh Knoke [16] digunakan dalam beberapa penelitian untuk menjelaskan alasan mengapa pegawai melakukan withholding effort (Tsay dan Lin [17]). Model tersebut terbagi menjadi tiga perspektif yakni konformitas normatif, ikatan afektif dan pilihan rasional (Lin dan Huang [2], Kidwell dan Bennett [1]). Pertama, konformitas normatif adalah persepsi anggota kelompok kerja atas norma rekan kerja seperti kepatuhan, keadilan, dan kesetaraan. Contohnya, jika anggota melihat anggota kelompok melakukan perilaku withholding effort maupun ketidaksetaraan dalam kelompok kerja mereka, mereka cenderung membalas dengan melakukan hal serupa. Kedua, ikatan afektif adalah rasa kasih sayang dan keterikatan emosional antara anggota atau kelompok. Rasa kesatuan antara pegawai dengan unit kerja akan memperkuat motif pegawai untuk berkontribusi pada organisasi. Variabel seperti kohesi kelompok, hubungan interpersonal, saling menghormati, tingkat turn over kelompok berkaitan erat dengan ikatan afektif. Ketiga, pilihan rasional mengacu pada fakta bahwa seseorang akan membuat "keputusan yang rasional" berdasarkan pada manfaat/biaya pada evaluasi dalam diri atas lingkungan kerja mereka. Keputusan rasional tersebut dibuat berdasarkan pertimbangan pekerjaan dan lingkungan kerja seperti evaluasi pekerjaan yang dilakukan oleh atasan apakah menyebabkan dirinya mendapatkan pengawasan yang baik.

Beberapa penelitian sebelumnya memfokuskan pada faktor yang mampu mempengaruhi withholding effort karena perilaku itu sangat merugikan organisasi. Hassan [18] mengemukakan bahwa terjadinya withholding effort berupa social loafing dikarenakan beberapa faktor yakni kurangnya sistem remunerasi yang adil baik dari segi distribusi dan prosedural, kurangnya kohesivitas kelompok, dan kurangnya evaluasi dan pengawasan kontribusi kerja kelompok.

Pegawai akan menyesuaikan kontribusi kerja pada persepsi keadilan distributif dari penghargaan yang diberikan (Latham dan Pinder [19]). Meningkatkan persepsi keadilan dalam pemberian remunerasi maka organisasi dapat mendorong pegawainya untuk meningkatkan kontribusi kerja dan akhirnya mampu mencapai efisiensi ekonomis dalam organisasi (Abeler et al. [20], Jawahar dan Stone [21]). Kontribusi kerja pegawai dipengaruhi oleh persepsi keadilan dari remunerasi yang diterima dan pegawai akan melakukan withholding effort ketika remunerasi yang diterima kurang dari remunerasi yang sesuai dengan kontribusi kerja mereka (Charness et al. [22]). Keadilan organisasi adalah aspek fundamental dalam sistem kompensasi. Kewajaran struktur dan daya saing kompensasi dapat dinilai dari segi keadilan distribusi serta keadilan prosedural (Cohen-Charash dan Spector [23], Misra et al. [24]; Mondy dan Noe [25], Hasibuan [26], Sancoko [27]). Ini berarti semakin adil keadilan remunerasi yang dirasakan oleh pegawai, maka 
semakin menurun kecenderungan melakukan withholding effort.

Pegawai tidak melakukan withholding effort, jika mereka tahu bahwa atasan mereka menunjukkan keahlian dan konsiderasi (Kidwell dan Bennett [1]). Hodson [28] dalam bukunya menunjukkan bahwa atasan langsung dengan perilaku yang abusive saat bekerja menimbulkan sikap negatif dari pegawai seperti meningkatnya persentase ketidakhadiran dan withholding effort, namun terdapat hubungan yang lebih erat antara atasan yang tidak memiliki kompetensi dengan sikap negatif yang ditunjukkan oleh pegawai. Pegawai tidak suka dengan atasan yang abusive, namun lebih tidak suka dengan atasan yang tidak kompeten. Dari berbagai penelitian pendukung yang mendasari model kompetensi umum dapat ditemukan beberapa kategorisasi yang menggabungkan kompetensi dengan kategori yang mirip atau yang serupa (Gibbons et al. [29], Mumford et al. [30], Arthur et al. [31]). Kompetensi terbagi atas tiga yakni kompetensi yang berkaitan dengan pekerjaan, sosial, dan diri sendiri (Analoui et al. [32], Hsieh et al. [33]). Ini berarti semakin kompeten seorang atasan dinilai oleh bawahannya, maka semakin menurun kecenderungan melakukan withholding effort.

Berdasarkan teori pertukaran sosial, ketika seorang individu merasakan bahwa mereka terlibat dalam hubungan kelompok yang erat, maka mereka akan memberikan upaya lebih dalam hubungan timbal balik dalam kelompok (Murphy et al. [34]). Penelitian sebelumnya dalam lomba olahraga renang individu dan estafet membuktikan bahwa terdapat hubungan kohesivitas kelompok dengan social loafing yang dioperasionalkan pada perbedaan upaya dalam lomba individu dan lomba estafet (Gammage et al. [35]). Kohesivitas kelompok didefinisikan sebagai proses dinamis yang tercermin dalam kecenderungan kelompok untuk tetap bersama-sama dan tetap bersatu akibat adanya ketertarikan antar anggota untuk mencapai tujuan kelompok (Gammage et al. [35], Pescosolido dan Saavedra [36]). Kohesivitas kelompok telah lama dikenal sebagai variabel penting yang berhubungan dengan social loafing, salah satu bentuk withholding effort (Liden et al. [37]). Beberapa penelitian terdahulu membuktikan adanya hubungan negatif antara kohesivitas kelompok dengan withholding effort khususnya social loafing dan job neglect (Kidwell dan Bennett [1]; Duffy dan Shaw [38]). Ini berarti semakin kuat kohesivitas kelompok yang dirasakan oleh pegawai, maka semakin menurun kecenderungan melakukan withholding effort.

Berdasarkan paparan tersebut, dirancang kerangka konsep penelitian seperti pada Gambar 1.

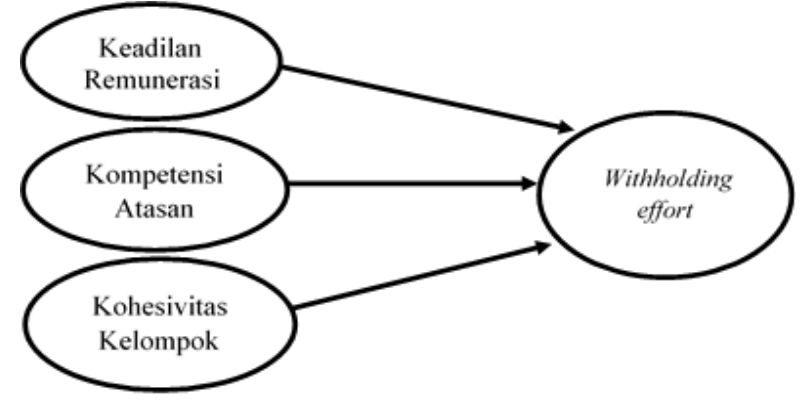

Gambar 1. Kerangka konsep penelitian

\section{Metode Penelitian}

Populasi dalam penelitian ini berjumlah 80 orang yang terdiri dari 3 orang calon pegawai negeri sipil dan 77 pegawai negeri sipil yang aktif di Institut Hindu Dharma Negeri Denpasar. Ketiga calon pegawai negeri sipil tersebut sudah bekerja lebih dari satu tahun, dan pada bulan Oktober 2016 telah diangkat menjadi pegawai negeri sipil. Jika populasi kurang dari 100, maka disarankan dipergunakan semua sehingga penelitian ini dapat disebut penelitian populasi (Sugiyono [39]). Jumlah populasi kurang dari 100 maka populasi dapat langsung dijadikan sampel.

Variabel bebas yaitu variabel yang memiliki pengaruh terhadap variabel terikat, namun tidak dipengaruhi oleh variabel lain dalam model. Dalam penelitian ini variabel bebas adalah keadilan remunerasi (X1), kompetensi atasan (X2) dan kohesivitas kelompok (X3). Keadilan Remunerasi yakni persepsi keadilan dari remunerasi yang diterima oleh pegawai diukur melalui dua indikator (Misra et al. [24], Mondy dan Noe [25], Hasibuan [26], Sancoko [27]) : (1) keadilan prosedural (X1.1) yaitu persepsi keadilan yang dirasakan pegawai atas struktur remunerasi, aturan, prosedur dan informasi yang menyertai pelaksanaannya; (2) keadilan distributif (X1.2) yaitu persepsi pegawai atas kewajaran remunerasi yang diterima, rasio antara kontribusi pegawai (input) dan remunerasi yang diterima relevan dengan orang lain.

Kompetensi atasan adalah kemampuan yang dimiliki atasan untuk menghadapi berbagai tugas yang dihadapi selama bekerja. Indikator kompetensi atasan meliputi (Vaculik et al. [40]) : (1) kompetensi yang berkaitan dengan pekerjaan (X2.1) yaitu persepsi pegawai atas kemampuan atasan secara efektif mengelola pekerjaan, menjadi teladan, memahami permasalahan, mengantisipasi risiko dan mengevaluasi hasil kerja bawahan; (2) kompetensi yang berkaitan dengan hubungan sosial (X2.2) yaitu persepsi pegawai atas kemampuan atasan melakukan hubungan baik dengan bawahan, menghargai pendapat bawahan dan mengembang- 
kan bawahan; dan (3) kompetensi yang berkaitan dengan diri sendiri (X2.3) yaitu persepsi pegawai atas kemampuan atasan dalam melakukan introspeksi diri, keadilan dan keterbukaan.

Kohesivitas kelompok adalah perasaan saling memiliki dan terkait satu dengan anggota yang lain akibat interaksi selama bekerja dalam unit kerja. Indikator kohesivitas kelompok meliputi (Forsyth [41]): (1) kohesi sosial (X3.1) yaitu ketertarikan anggota pada kelompok/unit kerja, baik itu anggotanya maupun terhadap unit itu sendiri; (2) kohesi tugas (X3.2) yaitu kapasitas yang ditunjukkan sebagai kelompok yang saling berkoordinasi dan menjadi bagian dari unit kerja secara sukses; (3) kohesi yang dirasakan (X3.3) yaitu persepsi pegawai dalam memandang anggota kelompok/unit sebagai suatu keseluruhan di mana mereka merasa diakui dalam unit kerja tersebut sebagai suatu identitas; dan (4) kohesi emosional (X3.4) yaitu intensitas emosi kelompok dan individu ketika berada dalam unit kerja.

Variabel terikat yaitu variabel yang dipengaruhi oleh variabel bebas dalam model. Dalam penelitian ini variabel terikat adalah withholding effort $(\mathrm{Y})$. Withholding effort adalah upaya pengurangan kontribusi kerja yang secara sengaja dilakukan oleh pegawai selama bekerja. Indikator withholding effort meliputi (Kidwell dan Robie [8]: (1) shirking (Y.1) yaitu kecenderungan pegawai saat bekerja sendiri dengan memberikan kontribusi kerja yang kurang maksimal dan tidak mendapatkan konsekuensi apapun; (2) job neglect (Y.2) yaitu kecenderungan pegawai untuk meninggalkan dan/atau menunda pekerjaan demi preferensi urusan pribadi saat bekerja sendiri; (3) social loafing (Y.3) yaitu melakukan pekerjaan tidak maksimal pada saat berada dalam kelompok kerja; dan (4) free riding (Y.4) yaitu tidak memberikan kontribusi kerja apapun saat bekerja dalam unit kerja karena output yang didapatkan dibagi rata kepada seluruh anggota organisasi.

Analisis regresi yang baik adalah yang telah lolos uji asumsi klasik. Uji asumsi klasik yang digunakan adalah uji normalitas, uji multikolinieritas dan uji heteroskedastisitas. Pengujian Goodness model fit (kelayakan model) mempergunakan uji F. Apabila $\mathrm{F}_{\text {tabel }}$ lebih kecil dari $\mathrm{F}_{\text {hitung }}$ atau $\mathrm{P}_{\text {Value }} \leq 0,05$, maka model dikatakan layak. Dari uji $\mathrm{F}$ didapatkan koefisien determinasi $\left(R^{2}\right)$ dari model. Koefisien determinasi pada intinya mengukur sejauh mana kemampuan model menerangkan tingkatan variasi variabel terikat (Ghozali [42]).

Nilai koefisien determinasi berada diantara nol dan satu. Jika memiliki nilai kecil berarti tingkat kemampuan variabel-variabel bebas untuk menjelaskan variasi variabel terikat sangat rendah. Jika hampir menyentuh angka satu berarti variabelvariabel bebas mampu menjelaskan semua informasi yang dibutuhkan untuk memprediksi variasi variabel terikat. Adanya kelemahan pada koefisien determinasi $\left(\mathrm{R}^{2}\right)$ yakni bias terhadap jumlah variabel bebas yang dimasukkan ke dalam model menyebabkan adanya pertimbangan untuk menggunakan nilai Adjusted $\mathrm{R}^{2}$. Nilai Adjusted $\mathrm{R}^{2}$ dapat turun dan naik apabila satu variabel bebas ditambahkan ke dalam model.

Uji-t digunakan untuk menguji pengaruh variabel bebas secara individu terhadap variabel terikat. Jika $\mathrm{P}_{\text {Value }}$ menunjukkan angka kurang dari 0,05, maka hubungan antara variabel bebas dan terikat adalah signifikan.

\section{Hasil dan Pembahasan}

Pengujian validitas dapat dilakukan dengan menggunakan korelasi product moment yang menghubungkan skor total indikator dengan skor total variabel (Sugiyono [39]). Jika koefisien korelasi sama dengan 0,30 atau lebih (paling kecil 0,30) maka butir instrumen dinyatakan valid. Berdasarkan Tabel 1, seluruh koefisien korelasi butir pada masing-masing variabel yang diteliti telah lebih dari 0,3 sehingga butir yang digunakan dalam penelitian ini dikatakan valid dan layak digunakan untuk seluruh responden yang telah ditargetkan.

Pengukuran reliabilitas dapat dilakukan dengan one shot atau pengukuran sekali saja. Pengukurannya hanya sekali dan kemudian hasilnya dibandingkan dengan pertanyaan lain atau mengukur korelasi antar jawaban pertanyaan. Alat untuk mengukur reliabilitas adalah Cronbach's Alpha (a). Suatu variabel dikatakan reliabel, apabila nilai $\alpha>0,60$ (Ghozali [42]). Tabel 1 menunjukkan bahwa seluruh variabel yang digunakan dalam penelitian memiliki koefisien korelasi Cronbach's Alpha lebih dari 0,6. Hal ini berarti semua variabel dalam penelitian ini dinyatakan reliabel, dan instrumen dapat dilanjutkan untuk digunakan pada seluruh responden yang telah ditargetkan (lihat Tabel 1).

Tabel 1. Hasil uji validitas dan reliabilitas

\begin{tabular}{lcc}
\hline \multicolumn{1}{c}{ Variabel } & $\begin{array}{c}\text { Product } \\
\text { moment } \\
\text { correlation } \\
\text { (validitas) }\end{array}$ & $\begin{array}{c}\text { Cronbach's } \\
\text { Alpha } \\
\text { (Reliabilitas) }\end{array}$ \\
\hline Keadilan remunerasi (X1) & $0,774-0,901$ & 0,811 \\
Kompetensi atasan (X2) & $0,783-0,892$ & 0,879 \\
Kohesivitas kelompok (X3) & $0,657-0,880$ & 0,831 \\
Withholding effort $(\mathrm{Y})$ & $0,740-0,915$ & 0,842 \\
\hline
\end{tabular}




\section{Karakteristik Responden}

Informasi responden dari jenis kelamin sebagian besar adalah laki -laki, yaitu sebanyak 43 responden $(53,8 \%)$ dan sisanya adalah responden perempuan yaitu sebanyak 37 responden (46,2\%). Dari informasi jenis kelamin terdapat jumlah yang hampir seimbang bagi pegawai berjenis laki-laki dan perempuan. Karakteristik responden dari unit kerja sebagian besar dari Unit Rektorat - Biro Umum sebanyak 34 orang (42,5\%), responden dari Unit Rektorat - Biro Akademik sebanyak 20 orang (25\%), responden dari Unit Fakultas 18 orang $(22,5 \%)$ dan responden dari Unit Pascasarjana paling sedikit yaitu berjumlah 8 orang (10\%). Dari informasi unit kerja yang disajikan mayoritas pegawai berada di unit kerja Rektorat - Biro Umum karena sebagian besar penggerak administrasi tersentralisasi pada Rektorat - Biro Umum seperti kepegawaian, umum, perencanaan dan keuangan.

Responden dengan masa kerja 5-9 tahun berada dalam peringkat pertama dengan jumlah 31 orang (38,8\%), responden dengan masa kerja 20-24 tahun berada diurutan kedua berjumlah 20 orang (25\%), responden dengan masa kerja 10-14 tahun berada diurutan ketiga berjumlah 17 orang $(21,2 \%)$, dan sisa responden memiliki sebaran yang sama untuk kelompok masa kerja 1-4 tahun, 15-19 tahun, 2529 tahun, 30-34 tahun masing-masing berjumlah 3 orang $(3,8 \%)$. Dari informasi masa kerja mayoritas pegawai IHDN Denpasar berada pada masa kerja 5-9 tahun karena pada tahun 2006-2011 IHDN Denpasar membuka formasi Calon Pegawai Negeri Sipil yang banyak karena pada saat itu IHDN Denpasar sangat membutuhkan banyak pegawai akibat meningkatnya status dari Sekolah Tinggi Agama Hindu menjadi Institut Hindu Dharma.

\section{Analisis Faktor}

Analisis faktor yang dipergunakan adalah confirmatory factor analysis. Confirmatory factor analysis digunakan apabila faktor yang terbentuk telah ditetapkan terlebih dahulu, merupakan bentuk analisis faktor yang mengkonfirmasikan beberapa konstruk empirik yang diasumsikan sebagai faktor dari konstruk laten sehingga dapat diketahui faktor yang paling dominan membentuk konstruk laten tersebut. Alat bantu analisisnya adalah dengan menggunakan program SPSS.

\section{Keadilan Remunerasi}

Dimensi yang memiliki loading factor tertinggi membentuk keadilan remunerasi adalah dimensi keadilan distributif - nilai remunerasi yang didapat dibandingkan kontribusi kerja yang diberikan dengan nilai 0,915 . Ini berarti bahwa pegawai merasa sangat penting perihal mewujudkan keadilan remunerasi dalam persepsi nilai remunerasi dengan kontribusi kerja yang diberikan. Selain indikator tersebut, yang mampu mencerminkan variabel keadilan remunerasi adalah prosedur perhitungan remunerasi yang jelas dan dipahami oleh masing-masing pegawai sehingga mereka mampu merasakan prosedur dari perhitungan sudah dilakukan secara adil oleh organisasi (lihat Tabel 2).

Tabel 2. Hasil loading factor dari variabel keadilan remunerasi

\begin{tabular}{llc}
\hline Dimensi Pernyataan & $\begin{array}{c}\text { Loading } \\
\text { factor }\end{array}$ \\
\hline X1.1.1 & $\begin{array}{l}\text { Proses penentuan job grade } \\
\text { remunerasi }\end{array}$ & 0,857 \\
X1.1.2 & Prosedur perhitungan remunerasi \\
X1.1.3 & $\begin{array}{l}\text { Informasi tentang remunerasi yang } \\
\text { didapatkan }\end{array}$ & 0,909 \\
& 0,873 \\
Xeadilan distributif (X1.2) & \\
K1.2.1 & $\begin{array}{l}\text { Nilai remunerasi yang didapatkan } \\
\text { dengan kontribusi kerja yang }\end{array}$ & 0,915 \\
diberikan & 0,828 \\
X1.2.2 & $\begin{array}{l}\text { Nilai remunerasi yang didapatkan } \\
\text { dengan beban kerja yang dimiliki }\end{array}$ & 0,841 \\
X1.2.3 & $\begin{array}{l}\text { Nilai remunerasi yang didapatkan } \\
\text { dengan kebutuhan hidup pegawai }\end{array}$ & 0,791 \\
X1.2.4 & $\begin{array}{l}\text { Nilai remunerasi yang diterima } \\
\text { dengan nilai remunerasi pegawai } \\
\text { lain di instansi yang serupa }\end{array}$ & \\
\hline
\end{tabular}

Tabel 3. Hasil loading factor dari variabel kompetensi atasan

\begin{tabular}{llc}
\hline Dimensi & \multicolumn{1}{c}{ Pernyataan } & $\begin{array}{c}\text { Loading } \\
\text { factor }\end{array}$ \\
\hline & $\begin{array}{l}\text { Kompetensi yang berkaitan dengan } \\
\text { pekerjaan (X2.1) }\end{array}$ & \\
X2.1.1 & Kemampuan menjadi teladan & 0,905 \\
X2.1.2 & Kemampuan memahami \\
permasalahan & 0,921 \\
X2.1.3 & Kemampuan mengantisipasi risiko & 0,855 \\
X2.1.4 & Kemampuan mengevaluasi hasil & 0,845 \\
& tugas bawahan & \\
& Kompetensi yang berkaitan dengan \\
hubungan sosial (X2.2) & \\
X2.2.1 & Kemampuan menghargai pendapat & 0,904 \\
& bawahan \\
X2.2.2 & Kemampuan memberikan pujian & 0,905 \\
X2.2.3 & Kemampuan melibatkan bawahan & 0,905 \\
& pada pengalaman kerja baru & \\
& Kompetensi yang berkaitan dengan & \\
diri sendiri (X2.3) & \\
X2.3.1 & Kemampuan penawaran bantuan & 0,888 \\
bila dibutuhkan & \\
X2.3.2 & Kemampuan mengakui kesalahan & 0,862 \\
X2.3.3 & Kemampuan berperilaku adil & 0,858 \\
\hline
\end{tabular}




\section{Kompetensi Atasan Langsung}

Dimensi yang memiliki loading factor tertinggi membentuk kompetensi atasan langsung adalah dimensi kompetensi atasan langsung yang berkaitan dengan pekerjaan-kemampuan memahami permasalahan dengan nilai 0,921 . Ini berarti bahwa pegawai merasa sangat penting perihal mewujudkan persepsi mengenai kompetensi atasan langung dalam kemampuan untuk memahami masalah yang dihadapi oleh bawahannya. Selain itu, indikator yang mampu mencerminkan kompetensi atasan langsung adalah kemampuan menjadi teladan, kemampuan memberikan pujian dan kemampuan melibatkan bawahan pada pengalaman kerja baru. Indikator tersebut yang mampu membentuk persepsi pegawai IHDN Denpasar dalam menggambarkan kompetensi atasan langsung yang ideal (lihat Tabel 3).

\section{Kohesivitas Kelompok}

Dimensi yang memiliki loading factor tertinggi membentuk kohesivitas kelompok adalah dimensi kohesi yang dirasakan-perasaan menyatu dalam satu unit dengan nilai 0,847 . Ini berarti bahwa pegawai merasa sangat penting perihal mewujudkan persepsi mengenai kohesivitas kelompok melalui perasaan menyatu dalam satu unit. Selain itu, indikator yang mampu merefleksikan kohesivitas kelompok adalah persepsi koordinasi dalam unit kerja. Unit kerja yang mampu melakukan koordinasi dengan baik melalui komunikasi yang terhubung sedemikian rupa mampu mewujudkan gambaran kohesivitas kelompok yang baik bagi pegawai IHDN Denpasar (lihat Tabel 4).

\section{Withholding Effort}

Dimensi yang memiliki loading factor tertinggi membentuk withholding effort adalah dimensi free riding-kepedulian terhadap reputasi unit tempat bekerja dengan nilai 0,922. Artinya keputusan melakukan withholding effort dibentuk dari persepsi kepedulian terhadap reputasi unit tempat bekerja. Kepedulian yang rendah pada reputasi unit tempat kerja akan membuat pegawai tidak termotivasi untuk memberikan kontribusi kerja karena pada dasarnya reputasi unit kerja bukanlah hal penting bagi pribadi pegawai. Selain itu, indikator yang mampu merefleksikan withholding effort adalah social loafing-tingkat kecenderungan melamun saat bekerja. Kecenderungan melamun saat bekerja dapat terjadi akibat kurangnya rasa inisiatif pada pegawai untuk melakukan pekerjaan di luar tugas pokok dan fungsi pegawai. Kurangnya inisiatif dapat disebabkan oleh penilaian kinerja maupun prestasi belum memasukkan inisiatif dan kreatifitas dalam indikator penilaian kinerja yang penting (lihat Tabel 5).

\section{Uji Asumsi Klasik}

Hasil uji asumsi klasik dari analisis regresi linier berganda ini menunjukkan bahwa analisis regresi lolos dari uji asumsi klasik ditunjukkan oleh uji normalitas yang menghasilkan Asymp.sig (2-tailed) $0,780>$ tingkat signifikansi $(\alpha=5 \%)$. Uji multikolinieritas menunjukkan nilai variance inflation factor (VIF) berada di bawah 10 sehingga dapat disimpulkan bahwa tidak terjadi multikolinieritas antar variabel bebas dalam model regresi. Uji heteroskedastisitas menunjukkan tingkat signifikansi berada di atas 0,05 yakni 0,$346 ; 0,779$ dan 0,776 maka model regresi ini bebas dari gejala heterokedastisitas (lihat Tabel 6).

\section{Uji Kelayakan Model/Goodness of Fit (Uji - F)}

Hasil $\mathrm{F}_{\text {hitung }}$ adalah 34,689 , nilai signifikansinya 0,000 lebih kecil dari $\alpha=0,05$, berarti model regresi layak digunakan, dan selanjutnya dapat dilakukan pengujian hipotesis. Koefisien determinasi juga digunakan untuk menguji goodness-fit dari model regresi.

Tabel 4. Hasil loading factor dari variabel kohesivitas kelompok

\begin{tabular}{|c|c|c|}
\hline Dimensi & Pernyataan & $\begin{array}{l}\text { Loading } \\
\text { factor }\end{array}$ \\
\hline & Kohesi sosial (X3.1) & \\
\hline X3.1.1 & $\begin{array}{l}\text { Persepsi teman dekat yang } \\
\text { dimiliki dalam unit kerja }\end{array}$ & 0,782 \\
\hline $\mathrm{X} 3.1 .2$ & $\begin{array}{l}\text { Perasaan dalam unit kerja yang } \\
\text { sekarang }\end{array}$ & 0,800 \\
\hline \multirow[t]{2}{*}{ X3.1.3 } & $\begin{array}{l}\text { Keinginan untuk pindah dari unit } \\
\text { sekarang }\end{array}$ & 0,789 \\
\hline & Kohesi tugas (X3.2) & \\
\hline $\mathrm{X} 3.2 .1$ & $\begin{array}{l}\text { Persepsi pada keefektifan unit } \\
\text { tempat kerja }\end{array}$ & 0,789 \\
\hline $\mathrm{X} 3.2 .2$ & $\begin{array}{l}\text { Persepsi atas kinerja unit tempat } \\
\text { kerja }\end{array}$ & 0,759 \\
\hline \multirow[t]{2}{*}{ X3.2.3 } & $\begin{array}{l}\text { Persepsi pada koordinasi dalam } \\
\text { unit kerja }\end{array}$ & 0,821 \\
\hline & Kohesi yang dirasakan (X3.3) & \\
\hline X3.3.1 & $\begin{array}{l}\text { Persepsi pada unit kerja } \\
\text { menjunjung persatuan sebagai } \\
\text { nilai penting }\end{array}$ & 0,812 \\
\hline X3.3.2 & $\begin{array}{l}\text { Persepsi pada unit kerja memiliki } \\
\text { ikatan anggota satu sama lain }\end{array}$ & 0,753 \\
\hline X3.3.3 & $\begin{array}{l}\text { Persepsi rasa menyatu dalam unit } \\
\text { kerja } \\
\text { Kohesi emosional }\end{array}$ & 0,847 \\
\hline $\mathrm{X} 3.4 .1$ & Persepsi pada energi kerja unit & 0,803 \\
\hline $\mathrm{X} 3.4 .2$ & $\begin{array}{l}\text { Persepsi pada semangat kerja unit } \\
\text { sebagai sebuah kelompok }\end{array}$ & 0,728 \\
\hline X3.4.3 & $\begin{array}{l}\text { Persepsi pada semangat kerja saat } \\
\text { bekerja dalam unit }\end{array}$ & 0,661 \\
\hline
\end{tabular}


Tabel 5. Hasil loading factor dari variabel withholding effort

\begin{tabular}{|c|c|c|}
\hline Dimensi & Pernyataan & $\begin{array}{l}\text { Loading } \\
\text { factor }\end{array}$ \\
\hline & Withholding effort $(\mathrm{Y})$ & \\
\hline & Shirking (Y.1) & \\
\hline Y.1.1 & $\begin{array}{l}\text { Tingkat penghindaran menjadi } \\
\text { panitia pengadaan barang dan jasa }\end{array}$ & 0,873 \\
\hline Y.1.2 & $\begin{array}{l}\text { Tingkat penghindaran menjadi } \\
\text { panitia pengadaan barang dan jasa } \\
\text { dimasa yang akan datang } \\
\text { Job Neglect (Y.2) }\end{array}$ & 0,863 \\
\hline Y.2.1 & $\begin{array}{l}\text { Tingkat kecenderungan } \\
\text { menghabiskan waktu istirahat } \\
\text { dari waktu yang ditetapkan }\end{array}$ & 0,854 \\
\hline Y.2.2 & $\begin{array}{l}\text { Tingkat kecenderungan memilih } \\
\text { urusan pribadi dibandingkan } \\
\text { urusan pekerjaan }\end{array}$ & 0,819 \\
\hline Y.2.3 & $\begin{array}{l}\text { Tingkat kecenderungan untuk } \\
\text { berpura-pura sakit untuk } \\
\text { menghindari pekerjaan }\end{array}$ & 0,861 \\
\hline & Social Loafing (Y.3) & \\
\hline Y.3.1 & $\begin{array}{l}\text { Tingkat kecenderungan melamun } \\
\text { pada saat jam kerja }\end{array}$ & 0,915 \\
\hline Y.3.2 & $\begin{array}{l}\text { Tingkat kecenderungan tidak } \\
\text { membantu pekerjaan teman lain } \\
\text { ketika pekerjaan sudah selesai }\end{array}$ & 0,859 \\
\hline Y.3.3 & $\begin{array}{l}\text { Tingkat kecenderungan tidak } \\
\text { berkontribusi dalam satu } \\
\text { kelompok kerja }\end{array}$ & 0,880 \\
\hline Y.3.4 & $\begin{array}{l}\text { Tingkat kecenderungan bersikap } \\
\text { santai walaupun teman satu unit } \\
\text { sedang sibuk bekerja }\end{array}$ & 0,862 \\
\hline & Free Riding (Y.4) & \\
\hline Y.4.1 & $\begin{array}{l}\text { Tingkat kepedulian dengan } \\
\text { lingkungan kerja yang kotor }\end{array}$ & 0,888 \\
\hline Y.4.2 & $\begin{array}{l}\text { Tingkat kecenderungan tidak } \\
\text { membantu pengunjung yang } \\
\text { kebingungan mencari unit lain }\end{array}$ & 0,887 \\
\hline Y.4.3 & $\begin{array}{l}\text { Tingkat kepedulian dengan } \\
\text { reputasi unit tempat bekerja }\end{array}$ & 0,922 \\
\hline Y.4.4 & $\begin{array}{l}\text { Tingkat kepedulian dengan } \\
\text { serapan anggaran IHDN Denpasar }\end{array}$ & 0,888 \\
\hline
\end{tabular}

Tabel 6. Rangkuman hasil analisis regresi linier berganda

\begin{tabular}{ccccc}
\hline $\begin{array}{c}\text { Variabel } \\
\text { terikat }\end{array}$ & \multicolumn{1}{c}{$\begin{array}{c}\text { Variabel } \\
\text { bebas }\end{array}$} & $\begin{array}{c}\text { Unstandar- } \\
\text { dized } \\
\text { coefficients }\end{array}$ & t-hitung & Sig \\
\hline $\begin{array}{l}\text { Withholding } \\
\text { effort }(\mathrm{Y})\end{array}$ & $\begin{array}{l}\text { Keadilan } \\
\text { remunerasi } \\
\text { (X1) }\end{array}$ & $-0,457$ & $-4,827$ & 0,000 \\
& $\begin{array}{l}\text { Kompetensi } \\
\text { atasan }\end{array}$ & $-0,181$ & $-2,055$ & 0,043 \\
& $\begin{array}{l}\text { langsung } \\
\text { (X2) }\end{array}$ & & & \\
& $\begin{array}{l}\text { Kohesivitas } \\
\text { kelompok } \\
\text { (X3) }\end{array}$ & $-0,287$ & $-3,304$ & 0,001 \\
& & & \\
\hline Constant $=0,009782$ & Adjusted $R$-square $=0,561$ \\
R-square $=0,578$ & F hitung $=34,689$ Sig $=0,000$ \\
\hline
\end{tabular}

Berdasarkan hasil output SPSS besarnya nilai adjusted $R^{2}$ yaitu 0,561 atau sama dengan $56,1 \%$ yang artinya pengaruh variabel bebas yaitu keadil- an remunerasi, kompetensi atasan langsung dan kohesivitas kelompok terhadap variabel terikat yaitu withholding effort sebesar 0,561 atau sama dengan 56,1\%, sisa nilai sebesar 0,439 atau sama dengan $43,9 \%$ dijelaskan oleh variabel lain yang tidak dimasukkan ke dalam penelitian ini.

\section{Uji Hipotesis (Uji-t)}

\section{Pengaruh Keadilan Remunerasi terhadap With- holding Effort}

Dari hasil perhitungan uji secara parsial diperoleh nilai thitung sebesar -4,827 dan nilai signifikan sebesar 0,000, maka hipotesis $\mathrm{H}_{0}$ ditolak $\mathrm{H}_{1}$ diterima, ini berarti terdapat pengaruh negatif variabel keadilan remunerasi (X1) terhadap withholding effort (Y). Keadilan remunerasi diukur dengan keadilan prosedural dan keadilan distributif. Hasil penilaian pegawai, keadilan distributif dilihat dari kewajaran nilai remunerasi yang diterima serta keadilan prosedural mengenai prosedur remunerasi berdampak besar pada kecenderungan pegawai melakukan withholding effort. Semakin adil persepsi pegawai terhadap remunerasi yang diberikan, maka akan menekan perilaku withholding effort dari pegawai.

Hasil ini konsisten dengan hasil penelitian oleh Liden et al. [37] juga menunjukkan bahwa terdapat hubungan negatif yang signifikan antara keadilan prosedural dan social loafing (salah satu bentuk withholding effort); dan persepsi pegawai terhadap keadilan dalam prosedur pembagian remunerasi yang mempengaruhi kontribusi kerja dalam kerja kelompok. Berbagai dimensi keadilan remunerasi, seperti keadilan prosedural dan keadilan distributif dibutuhkan oleh para pegawai untuk memilih melakukan withholding effort. Ketika keadilan remunerasi yang dirasakan tidak adil maka tingkat withholding effort mereka akan menjadi tinggi.

\section{Pengaruh Kompetensi Atasan Langsung ter- hadap Withholding Effort.}

Dari hasil perhitungan uji secara parsial diperoleh nilai thitung sebesar -2,055 dan nilai signifikan sebesar 0,043, maka hipotesis $\mathrm{H}_{0}$ ditolak $\mathrm{H}_{2}$ diterima, ini berarti terdapat pengaruh negatif antara variabel kompetensi atasan langsung (X2) terhadap withholding effort $(\mathrm{Y})$. Kompetensi atasan langsung diukur dengan kompetensi yang berkaitan dengan tugas, kompetensi yang berkaitan dengan hubungan sosial dan kompetensi yang berkaitan dengan diri sendiri. Hasil penilaian pegawai, kompetensi atasan langsung dilihat dari kompetansi yang berkaitan dengan tugas, kompetensi yang berkaitan dengan hubungan sosial serta kompetensi yang berkaitan dengan diri sendiri berdampak pada kecenderungan 
pegawai melakukan withholding effort. Semakin kompeten atasan dipersepsikan oleh bawahan, maka semakin rendah kemungkinan mereka melakukan withholding effort.

Hasil dari penelitian ini konsisten dengan hasil penelitian oleh Hurley dan Ryman [43] yang menyatakan bahwan atasan yang tidak memiliki kemampuan dalam bersosialisasi dan hubungan baik dengan bawahan akan menyebabkan pegawai melakukan withholding effort karena mereka merasa bahwa atasan tidak peduli dengan bawahannya. Demikian pula penelitian yang dilakukan oleh Kidwell dan Bennett [1] yang menyatakan bahwa atasan harus mampu menilai apakah pekerjaan yang dilakukan baik atau tidak. Artinya, apabila atasan tidak memiliki kemampuan dan keahlian dalam penilaian hasil kerja maka bawahan akan menganggap bahwa atasan tidak memiliki kompetensi pada pekerjaan dan pada kesempatan berikutnya bawahan akan mengurangi kontribusi kerjanya karena hal tersebut tidak diawasi oleh atasannya. Berbagai dimensi kompetensi atasan langsung, seperti kompetensi yang berkaitan dengan tugas, kompetensi yang berkaitan dengan hubungan sosial dan kompetensi yang berkaitan dengan diri sendiri menjadi pertimbangan bawahan untuk memilih melakukan withholding effort. Ketika kompetensi atasan langsung dianggap tinggi oleh pegawai maka tingkat withholding effort akan menjadi rendah.

\section{Pengaruh Kohesivitas Kelompok terhadap With- holding Effort}

Dari hasil perhitungan uji secara parsial diperoleh nilai thitung sebesar -3,304 dan nilai signifikan sebesar 0,001, maka hipotesis $\mathrm{H}_{0}$ ditolak $\mathrm{H}_{3}$ diterima, ini berarti terdapat pengaruh negatif antara kohesivitas kelompok (X3) terhadap withholding effort (Y). Kohesivitas kelompok diukur dengan kohesi sosial, kohesi tugas, kohesi yang dirasakan dan kohesi emosional. Hasil penilaian pegawai, kohesivitas kelompok dilihat dari kohesi sosial yakni perasaan dalam unit, kohesi tugas yakni koordinasi dalam unit kerja, kohesi dirasakan yakni perasaan menyatu dalam unit dan kohesi emosional energi kerja dari unit kerja berdampak pada kecenderungan pegawai melakukan withholding effort. Semakin kuat kohesivitas kelompok yang dirasakan dalam unit kerja, maka semakin rendah kecenderungan pegawai melakukan withholding effort.

Hasil ini konsisten dengan temuan Tan dan Tan [44] yang menyatakan bahwa kohesivitas kelompok dapat mengurangi atau menghilangkan kecenderungan perilaku social loafing (salah satu bentuk withholding effort). Demikian pula dengan hasil penelitian Kidwell dan Bennett [45] yang menyatakan adanya hubungan negatif kohesivitas kelompok dengan withholding effort. Ketika kohesivitas kelompok dirasakan rendah oleh pegawai maka tingkat withholding effort mereka akan menjadi tinggi

\section{Simpulan}

Keadilan remunerasi berpengaruh negatif dan signifikan terhadap withholding effort yang berarti semakin adil remunerasi, mampu menekan kecenderungan pegawai melakukan withholding effort saat bekerja. Kompetensi atasan langsung berpengaruh negatif dan signifikan terhadap withholding effort yang berarti bahwa semakin kompeten atasan langsung, maka pegawai akan cenderung mengurangi withholding effort saat bekerja. Kohesivitas kelompok berpengaruh negatif dan signifikan terhadap withholding effort yang berarti bahwa semakin pegawai merasa kohesivitas kelompok yang kuat, maka pegawai akan cenderung mengurangi withholding effort saat bekerja.

Pembuat kebijakan pada Kementerian Agama harus mempertimbangkan sistem remunerasi yang lebih mempertimbangkan kontribusi kerja pada nilai yang didapatkan oleh pegawai serta secara berkesinambungan membuat program yang mampu meningkatkan pemahaman pegawai terhadap prosedur remunerasi khususnya tunjangan kinerja serta informasi yang berkaitan dengan pelaksanaan remunerasi tersebut. Kemampuan atasan yang perlu ditingkatkan adalah kemampuan mengevaluasi hasil kerja bawahan, memahami permasalahan dan mencoba bersama-sama memecahkan masalah tersebut, menjadi teladan agar bawahannya mengikuti perilaku dan sikap yang baik dari atasan, memberikan pujian agar mampu memotivasi bawahannya sehingga mendorong mereka bekerja menjadi lebih baik lagi, melibatkan bawahan pada pengalaman kerja baru sehingga bawahan terhindar dari kejenuhan dalam bekerja.

Kohesivitas kelompok harus didorong oleh semangat kerja dalam unit kerja. Semangat kerja dapat ditingkatkan melalui penanaman hasrat maju yang tinggi dalam diri pegawai, kebanggaan dalam organisasi dan mendorong rasa persatuan. Selain itu pentingnya meningkatkan koordinasi kerja dalam unit kerja maupun antar unit kerja secara umum sehingga pegawai merasa bahwa kohesi tugas yang dimiliki oleh unit kerja memang tinggi dan setiap anggota unit kerja mendukung tercapainya tujuan unit kerja. 


\section{Daftar Pustaka}

1. Kidwell, R.E., Jr., and Bennett, N., Perceived Work Context and Employee Job Neglect, American Business Review, 19(2), 2001, pp. 6474.

2. Lin, T.C., and Huang, C.C., Withholding Effort in Knowledge Contribution: The Role of Social Exchange and Social Cognitive on Project Teams, Information \& Management, 47(3), 2010, pp. 188-196.

3. Byrne, Z.S., Stoner, J., Thompson, K.R., and Hochwarter, W., The Interactive Effects of Conscientiousness, Work Effort and Psychological Climate on Job Performance, Journal of Vocational Behavior, 66(2), 2005, pp. 326-38.

4. Tracey, J.B., Sturman, M.C., and Tews, M.J., Ability versus Personality: Factors that Predict Employee Job Performance, Cornell Hotel and Restaurant Administration Quarterly, 48(3), 2007, pp. 313-322.

5. Morris, R.J., Employee Work Motivation and Discretionary Work Effort, Dissertation, Brisbane Graduate School of Bussiness, 2009.

6. Kidwell, R.E. and Martin, C., Managing Organizational Deviance, Sage Publishing, USA, 2005.

7. Sagie, A., Birati, A., and Tziner, A., Assessing the Costs of Behavioral and Psychological Withdrawal: A New Model and an Empirical Illustration, Applied Psychology: An International Review, 51(1), 2002, pp. 67-89.

8. Kidwell, R.E., Jr., and Robie, C., Withholding Effort In Organizations: Toward Development and Validation of a Measure, Journal of Business and Psychology, 17, 2003, pp. 537-561.

9. Kemenag, Menteri Agama: Dengan Satuan Kerja Terbesar, Perubahan Kementrian Agama Memerlukan Waktu, kemenag.go.id/index.php? $a=b e r i t a \& i d=324373$, diakses 25 Januari 2016.

10. Menpan, Rapor Akuntabilitas Kinerja K/L dan Provinsi. 2016, http://www.menpan.go.id/beritaterkini/4170-rapor-akuntabilitas - kinerja - k - 1dan - provinsi - meningkat, diakses tanggal 15 Januari 2016.

11. Herriyanto, H., Faktor-Faktor yang Mempengaruhi Keterlambatan Penyerapan Anggaran Belanja pada Satuan Kerja Kementerian/ Lembaga di Wilayah Jakarta, Thesis, Jakarta: Fakultas Ekonomi, Universitas Indonesia, 2012.

12. Cropanzano, R., and Mitchell, Marie S., Social Exchange Theory: An Interdisciplinary Review, Journal of Management, 31(6), 2005, pp. 874900.

13. van Knippenberg, D., van Dick, R., and Tavares, S., Social Identity and Social Exchange: Identification, Support, and Withdrawal from the Job, Journal of Applied Social Psychology, 37(3), 2007, pp. 457-477.
14. Homans, G.C., Social Behavior as Exchange, American Journal of Sociology, 63, 1958, pp. 597-606.

15. Coyle-Shapiro, J.A.M., and Neuman, J.H., The Psychological Contract and Individual Differences: The Role of Exchange and Creditor Ideologies, Journal of Vocational Behavior, 64, 2004, pp. $150-164$.

16. Knoke, D., Organizing for Collective Action: The Political Economies of Associations, Aldine de Gruyter, New York, 1990.

17. Tsay, C.H.H., and Lin, T.C., Knowledge Withholding Intentions in Teams: The Roles of Normative Conformity, Affective Bonding, Rational Choice and Social Cognition, Decision Support Systems, 67, 2014, pp. 53-65.

18. Hassan, E.S., Investigate the Major Reasons That Increase Social Loafing in a Team to Improve Morale and Team Productivity, Thesis, Open University Malaysia, 2010.

19. Latham, G.P., and Pinder, C.C., Work Motivation Theory and Research at the Dawn of The Twenty-first Century, Annual Review of Psycho$\log y$, Vol, 56, 2005, pp. 485-516.

20. Abeler, J., Altmann, S., Goerg, J.S., Kube, S., and Wibral, M., Equity and Efficiency in MultiWorker Firms: Insights for Experimental Economics, Analyse \& Kritik, No. 1, 2011, pp. 325-348.

21. Jawahar, I.M., and Stone, H.T., Fairness Perceptions and Satisfaction with Components of Pay Satisfaction, Journal of Managerial Psychology, 26(4), 2011, pp. 297-312.

22. Charness, G., Gross, T., and Guo, C., Merit Pay and Wage Compression with Productivity Differences and Uncertainty, Journal of Economic Behavior \& Organization, 2014, pp. 233-247.

23. Cohen-Charash, Y., and Spector, P.E., The Role of Justice in Organizations: A Meta-Analysis, Organizational Behavior \& Human Decision Processes, 86, 2001, pp. 278-321.

24. Misra, P., Rana, N., and Dixit, V., Compensation: Impact of Rewards, Organisational Justice on Job Satisfaction and Turnover Intentions in Retail Store Operations - A Study of Delhi and NCR, Proceedings of the International Conference on Business Management dan Information Systems, 2012.

25. Mondy, R.W., and Noe III, R.M., Human Resource Management, Fifth Edition, Allyn and Bacon, USA, 1992.

26. Hasibuan, M.S.P., Manajemen Sumber Daya Manusia, Edisi Revisi, PT.Bumi Aksara, Jakarta, 2007.

27. Sancoko, Bambang., Pengaruh Remunerasi terhadap Kualitas Pelayanan Publik, Bisnis dan Birokrasi, Jurnal Ilmu Administrasi dan Organisasi, 17(1), 2010, pp. 43-51.

28. Hodson, R., Dignity at Work, Cambridge University Press, England, 2001. 
29. Gibbons, A.M., Rupp, D.E., Snyder, L.A., Holub, S.A., and Woo, S.E., A Preliminary Investigation of Developable Dimensions, The Psychologist Manager Journal, 9(2), 2006, pp. 99-123.

30. Mumford, T.V., Campion, M.A., and Morgeson, F.P., The Leadership Skills Strataplex: Leadership Skill Requirements Across Organizational Levels, Leadership Quarterly, 18(2), 2007, pp. 154-166.

31. Arthur, W., Day, E.A., McNelly, T.L., and Edens, P.S., A Meta-Analysis of the Criterion-Related Validity of Assessment Center Dimensions, Personnel Psychology, 56(1), 2003, pp. 125-153.

32. Analoui, F., Labbaf, H., and Noorbakhsh, F., Identification of Clusters of Managerial Skills for Increased Effectiveness: The Case of the Steel Industry in Iran, International Journal of Training \& Development, 4(3), 2000, pp. 217-234.

33. Hsieh, S., Lin, J., and Lee, H., Analysis on Literature Review of Competency, International Review of Business and Economics, 2, 2012, pp. $25-50$.

34. Murphy, S.K., Wayne, S.J., Liden, R.C., and Erdogan, B., Understanding Social Loafing: The Role of Justice Perceptions and Exchange Relationships, Human Relations, 56, 2003, pp. 61-84.

35. Gammage, K.L., Carroon, A.V., and Estabrooks, P.A.2001.Team, Cohesiveness and Individual Productivity: The Influence of Norm for Productivity and Identifiability of Individual Effort, Small Group Research, 32(1), pp. 3-18.

36. Pescosolido, A.T., and Saavedra, R., Cohesion and Sports Teams: A Review, Small Group Research, 43(6), 2012, pp. 744-758.
37. Liden, R. C., Wayne, S. J., Jaworski, R. A., and Bennett, N., Social Loafing: A Field Investigation, Journal of Management, 30, 2004, pp. 285304.

38. Duffy, M.K., and Shaw, J.D., The Salieri Syndrome: Consequences of Envy in Groups, Small Group Research, 31(1), 2000, pp. 3-23.

39. Sugiyono, Metode Penelitian Pendidikan Pendekatan Kuantitatif, Kualitatif, dan $R \& D$. Alfabeta, Bandung, 2013.

40. Vaculik, M., Prochazka, J., and Smutny, P., Competencies and Leadership Effectiveness: Which Skills Predict Effective leadership? Academic Conferences and Publishing International Limited, 2014, pp. 337-344.

41. Forsyth, D., Group Dynamic, Fifth Edition, Needham Heights, Allyn and Bacon, MA, 2009.

42. Ghozali, I., Aplikasi Multivariate dengan Program SPSS, Badan Penerbit Universitas Diponegoro, Semarang, 2009.

43. Hurley, R., and Ryman, J., Making the Transition from Micromanager to Leader, Micromanagement Paper, Fordham University, 113, 2003, pp. 2-9.

44. Tan, H.H., and Tan, M.L., Organizational Citizenship Behavior and Social Loafing: The Role of Personality, Motives, and Contextual Factors, The Journal of Psychology, 142(1), 2008, pp. 89-108.

45. Kidwell, R.E., and Bennett, N., Employee Propensity to Withhold Effort: A Conceptual Model to Intersect Three Avenues of Research, Academy of Management Review, 18(3), 1993, pp. 429-456. 